\title{
Avaliação da Variabilidade do Grapevine leafroll-associated virus 1 e 3 por Análise de Seqüências de Nucleotídeos e Polimorfismo Conformacional de Fita Simples
}

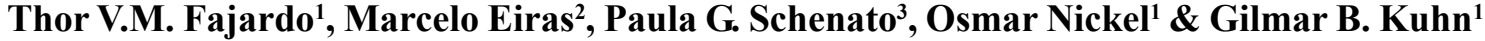 \\ ${ }^{1}$ Embrapa Uva e Vinho, Cx. Postal 130, CEP 95700-000, Bento Gonçalves, RS, e-mail:thor@cnpuv.embrapa.br; ${ }^{2}$ Centro de \\ Sanidade Vegetal, Instituto Biológico de São Paulo, Av. Conselheiro Rodrigues Alves, 1252, CEP 04014-002, São Paulo, SP; \\ ${ }^{3}$ Estudante de Biologia da Universidade de Caxias do Sul - CARVI, Bento Gonçalves, RS
}

(Aceito para publicação em 29/09/2004)

Autor para correspondência: Thor V.M. Fajardo

FAJARDO, T.V.M., EIRAS, M., SCHENATO, P.G., NICKEL, O. \& KUHN, G.B. Avaliação da variabilidade do Grapevine leafroll-associated virus 1 e 3 por análise de seqüências de nucleotídeos e polimorfismo conformacional de fita simples. Fitopatologia Brasileira 30:177-182. 2005.

\section{RESUMO}

As principais espécies de vírus envolvidas na etiologia do enrolamento da folha da videira (Vitis spp.) são Grapevine leafroll-associated virus 1 e 3 (GLRaV-1 e -3). Neste estudo da variabilidade desses vírus, foram amplificados dois fragmentos de DNA (396 bp do GLRaV-1 e 602 bp do GLRaV-3) por RT-PCR, a partir de RNA total extraído de nervuras e pecíolos de videiras infetadas, utilizando-se dois pares de oligonucleotídeos. Os DNAs amplificados foram clonados e reamplificados, a partir dos clones recombinantes, e comparados quanto às diferenças conformacionais das fitas simples desnaturadas (SSCP). Foram observados dois padrões distintos de perfis eletroforéticos para cada vírus, tendo sido seqüenciado pelo menos um clone viral correspondente a cada padrão. As duas seqüências de nucleotídeos obtidas para o GLRaV-1 apresentaram maior homologia $(79,8 \%$ e 87,4\%) com um isolado australiano e as duas seqüências relativas ao GLRaV-3 exibiram maior homologia $(75,1 \%$ e $81,8 \%)$ com um isolado norte-americano. Os resultados demonstraram a ocorrência de seqüências variantes destes vírus nas videiras analisadas.

Palavras-chave adicionais: videira, Vitis, GLRaV-1, GLRaV-3, SSCP.

\begin{abstract}
Evaluation of Grapevine leafroll-associated virus 1 and 3 variability by nucleotide sequence analysis and single-strand conformation polymorphism

The main viral species associated with grapevine (Vitis spp.) leafroll etiology are Grapevine leafroll-associated virus 1 and 3 (GLRaV-1 and -3). To partially evaluate the variability of these viruses, two DNA fragments (396 bp of GLRaV-1 and 602 bp of GLRaV-3) were amplified by RT-PCR using two sets of primers after total RNA extraction from veins and petioles of infected grapevines. The amplified DNA fragments were cloned and the reamplified viral DNAs, obtained from the recombinant clones, were studied with regard to denatured single-strand DNA conformational differences. Two different electrophoretic profiles were observed for each virus species. At least one viral clone representing each mobility profile was sequenced. The two nucleotide sequences obtained for GLRaV-1 showed the highest homologies $(79,8 \%$ and $87,4 \%)$ with an Australian isolate, whereas the two nucleotide sequences of GLRaV-3 exhibited the highest homologies $(75,1 \%$ and $81,8 \%)$ with a North American isolate. These results demonstrated the occurrence of GLRaV-1 and -3 sequence variants infecting the analysed grapevines.
\end{abstract}

Additional keywords: grapevine, Vitis, GLRaV-1, GLRaV-3, SSCP.

O enrolamento da folha, uma das principais doenças da videira (Vitis spp.), diminui a produção e a qualidade da uva (Fajardo et al., 2002) e pode ser causado por até nove espécies do Grapevine leafroll-associated virus (GLRaV), vírus associados ao floema. No Brasil, já foram relatados os vírus GLRaV-1, -2, -3 e -6, sendo as espécies GLRaV-1 e -3, família Closteroviridae, gênero Ampelovirus, as mais amplamente distribuídas e economicamente importantes. São vírus que possuem um único tipo de partícula, alongada e flexuosa, com cerca de $2000 \times 12 \mathrm{~nm}$. Apresentam o genoma composto por RNA fita simples, senso positivo, de cerca de $19 \mathrm{~kb}$ e massa molecular da proteína capsidial calculada em 35 a $37 \mathrm{kDa}$. Estas duas espécies são disseminadas de maneira semi-persistente por coccídeos e pseudococcídeos, transmitidas através da enxertia mas não são transmissíveis por inoculação mecânica (Fazeli \& Rezaian, 2000; Martelli et al., 2002; Martelli, 2003; Gugerli, 2003).

Os sintomas típicos de enrolamento dos bordos da folha para baixo são observados em cultivares européias de videira (Vitis vinifera L.), no final do ciclo vegetativo. Estes sintomas aparecem sempre nas folhas da base dos ramos, evoluindo para as demais folhas, podendo provocar o completo definhamento das plantas. Nas plantas muito afetadas, observa-se nos cachos maturação irregular eatrasada da uva. As videiras americanas (V. labrusca L.) e híbridas não mostram os sintomas característicos da virose e 
nos porta-enxertos o vírus é latente (Fajardo et al., 2003).

$\mathrm{O}$ único controle para o enrolamento da folha da videira é o uso de plantas comprovadamente sadias, provenientes de matrizes indexadas para o GLRaV. Para tal, podem ser utilizados métodos moleculares de diagnóstico por serem mais rápidos, precisos e de menor custo relativo quando comparados com o de enxertia em cultivares indicadoras (Fajardo et al., 2003). Para melhorar a eficácia do diagnóstico molecular é importante identificar e diferenciar estirpes e isolados virais.

A análise do polimorfismo conformacional de fitas simples do DNA Single-strand conformation polymorphism (SSCP) possibilita rápida diferenciação de fragmentos de DNA de mesmo tamanho, mas com variações na seqüência de nucleotídeos. Na análise de SSCP, o DNA de fita dupla é desnaturado por calor na presença de formamida e as fitas simples de DNA (ssDNA) são separadas por eletroforese em gel não desnaturante de poliacrilamida. A migração do ssDNA dependerá de sua conformação na condição eletroforética empregada que, por sua vez, depende da seqüência de nucleotídeos. Pequenas mudanças na seqüência de nucleotídeos podem alterar a conformação do ssDNA e, conseqüentemente, sua mobilidade eletroforética. Esta propriedade pode ser explorada para detectar mutações em fragmentos selecionados de DNA, desnaturando-os e comparando seus padrões eletroforéticos (Rubio et al., 1996).

A presença de diferentes seqüências de nucleotídeos para o mesmo vírus, às vezes na mesma planta, já foi verificada por meio de seqüenciamento e pelo perfil de SSCP, para o GLRaV-1 (Little et al., 2001), Grapevine virus A (GVA) (Goszczynski \& Jooste, 2002), Apple stem grooving virus (ASGV) (Magome et al., 1999) e Citrus tristeza virus (CTV) (Rubio et al., 1996; Souza et al., 2002). Entretanto, para se determinar quão significativas são estas diferenças observadas por SSCP, é necessário o seqüenciamento de nucleotídeos destes fragmentos. A análise por SSCP, que permite diferenciar seqüências de até uma base, constitui procedimento para identificar e diferenciar isolados virais, baseado na comparação de vários genes ou regiões gênicas, sendo rápida, de baixo custo e capaz de reduzir drasticamente a quantidade de seqüenciamento necessária para comparações acuradas (Rubio et al., 1996).

Este trabalho teve como objetivo avaliar parcialmente a variabilidade nos genomas de GLRaV-1 e GLRaV-3 por meio de análise de seqüências de nucleotídeos e polimorfismo conformacional de fita simples.

\section{Isolados virais}

As seqüências variantes de GLRaV-1 e GLRaV-3 foram obtidas, respectivamente, de videiras das cultivares Franciscana e Seibel mantidas em vasos, em casa de vegetação, na Embrapa Uva e Vinho, em Bento Gonçalves, RS.

\section{Extração de RNA total}

A extração de RNA total, a partir de $100 \mathrm{mg}$ de nervuras e pecíolos de folhas infetadas com GLRaV-1 e GLRaV-3 foi realizada utilizando-se o "RNeasy Plant Mini Kit" (Qiagen), com pequenas modificações. $\mathrm{O}$ tecido vegetal foi triturado em nitrogênio líquido, adicionaram-se a seguir $450 \mu 1$ do tampão isotiocianato de guanidina $4 \mathrm{M}$, acetato de sódio $0,2 \mathrm{M}, \mathrm{pH} 5,0$, EDTA $25 \mathrm{mM}$, PVP-40 a 2,5\% e 2-mercaptoetanol a $1 \%$ e incubaram-se as amostras por $3 \mathrm{~min}$ a $56^{\circ} \mathrm{C}$. As etapas seguintes foram executadas conforme recomendações do fabricante.

\section{Síntese do cDNA e RT-PCR}

Procedeu-se à síntese do cDNA viral e à PCR conforme Fajardo et al. (2002). Os pares de oligonucleotídeos LR1-1 $($ viral $)=5^{\prime}$ ACG TTG AGA TTA GTC TGA CTC 3' e LR1-2 $($ complementar $)=5^{\prime}$ TTC CGT GTC TAA CAT CCG TC 3', definidos por Habili et al. (1997), e HSP-P-1 (viral) = 5' GGN TTA GAN TTC GGN ACN AC 3' e HSP-P-2 (complementar) $=5^{\prime}$ TCA AAN GTN CCN CCN CCN AA 3' (Tian et al., 1996), foram usados, respectivamente, para a detecção de GLRaV-1 e -3. Foram executados 35 ciclos de amplificação (desnaturação, $94{ }^{\circ} \mathrm{C} / 1 \mathrm{~min}$; pareamento, $48{ }^{\circ} \mathrm{C} / 1 \mathrm{~min} \mathrm{e}$ extensão, $\left.72{ }^{\circ} \mathrm{C} / 1 \mathrm{~min}\right)$. Os produtos da amplificação foram analisados em gel de agarose $1,5 \%(\mathrm{p} / \mathrm{v})$, preparado em tampão TBE, pH 8,0. Os fragmentos de DNA de tamanho esperado foram eluídos utilizando-se o "GFX PCR DNA and Gel Band Purification Kit" (Amersham Biosciences), de acordo com as especificações do fabricante.

Os produtos da PCR para GLRaV-1 ou GLRaV-3, obtidos de diferentes plantas, foram individualmente visualizados em géis de agarose, sendo, posteriormente, misturados segundo a espécie viral, eluídos e clonados.

\section{Clonagem}

Os fragmentos de DNA ligados ao vetor pGEM-T Easy (Promega) foram utilizados na transformação, mediada por choque térmico, de células competentes de Escherichia coli DH5 $\alpha$. O DNA plasmidial das colônias bacterianas transformadas foi extraído utilizando-se o kit "Flexi Prep" (Amersham Biosciences).

\section{Análise de SSCP}

Os padrões de SSCP foram estimados nos genes virais reamplificados a partir do DNA extraído dos clones recombinantes. A $10 \mu \mathrm{l}$ da solução de DNA foi adicionado igual volume da solução desnaturante composta de formamida a $95 \% \mathrm{v} / \mathrm{v}$, azul de bromofenol a $0,05 \% \mathrm{v} / \mathrm{v}$ e $\mathrm{NaOH} 10 \mathrm{mM}$ (Goszczynski \& Jooste, 2002). A mistura foi desnaturada a $99^{\circ} \mathrm{C}$ por $15 \mathrm{~min}$, colocada em gelo por $2 \mathrm{~min}$ e os fragmentos separados por eletroforese, a 150 volts, por $3 \mathrm{~h}$, a $5{ }^{\circ} \mathrm{C}$, em gel de poliacrilamida a 7,5\% (Mini-protean II, Bio-Rad), utilizando o tampão TBE 0,5 X (Rubio et al., 1996). Os géis foram corados com brometo de etídeo, as bandas de DNA visualizadas sobre luz $\mathrm{UV}$ e fotodocumentadas. Os fragmentos observados foram analisados pela comparação das diferenças migratórias das fitas simples de DNA.

\section{Seqüenciamento e estudo de homologia de seqüências} Procedeu-se ao seqüenciamento automático de 
nucleotídeos de pelo menos um representante (clone viral) de cada padrão migratório de ssDNA observado. Esta abordagem foi executada para cada uma das duas espécies virais estudadas. As seqüências nucleotídicas obtidas foram comparadas entre si, dentro da mesma espécie viral, e também com as seqüências existentes no banco de dados GenBank, utilizando-se o programa BLAST do "National Center for Biotechnology Information" (http://www.ncbi.nlm.nih.gov).

Foram amplificados fragmentos de DNA de tamanhos esperados a partir de todas as amostras infetadas:396 bp no gene análogo ao da proteína capsidial (CPd2) do GLRaV-1 (ORF7=p50), entre os nucleotídeos 9691 e 10086 e em relação ao acesso AF 195822; e 602 bp, no gene da proteína homóloga à de choque térmico (HSP70) do GLRaV-3 (ORF4=p59), entre os nucleotídeos 10095 e 10696 e em relação ao acesso AF037268. Nos géis de agarose com os produtos da PCR não foi possível observar diferenças de migração entre os fragmentos obtidos para GLRaV-1 ou para GLRaV-3 (dados não mostrados).

Pela comparação das diferenças migratórias das fitas simples de DNA desnaturadas foi possível observar dois padrões distintos de bandas (com 1 ou 2 bandas por padrão) para cada espécie viral (Figuras 1A e 1B). É aceitável admitirse que a estrutura conformacional de ambas as fitas simples e complementares do DNA de um tipo de clone do GLRaV-1, linhas 2, 3, 5, 6 e 7 da Figura 1B, pode ser muito similar, determinando uma migração eletroforética que não permita a separação das bandas de ssDNA.
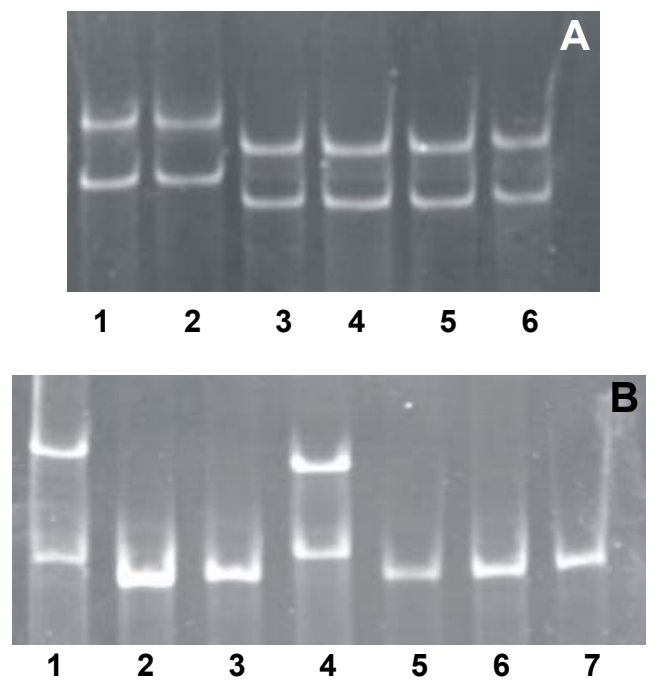

FIG. 1 - Padrão de bandas de DNA fita simples em gel de poliacrilamida a $7,5 \%$ para SSCP. (A) Com fragmento de $602 \mathrm{bp}$ obtido de diferentes isolados de Grapevine leafroll-associated virus (GLRaV-3). Poços 1 e 2 com clones que apresentaram 81,8\% de homologia e poços $3,4,5$ e 6 com clones que apresentaram $75,1 \%$ de homologia com isolado norte-americano de GLRaV-3; (B) Com fragmento de 396 bp obtido de diferentes isolados de GLRaV1. Poços 1 e 4 com clones que apresentaram 79,8\% de homologia e poços 2, 3, 5, 6 e 7 com clones que apresentaram $87,4 \%$ de homologia com isolado australiano de GLRaV-1.
Mais de duas bandas em um perfil de SSCP sugerem a presença de mais de uma seqüência variante na planta analisada, assim como verificado em relação ao GVA (Goszczynski \& Jooste, 2002). Devido à freqüente ocorrência de conformações de fitas simples de DNA secundárias e estáveis, as quais migram diferentemente em eletroforese (Rubio et al., 1996), a interpretação dos perfis de SSCP com mais de duas bandas é difícil e, em alguns casos, pode levar a conclusões errôneas em relação ao número de seqüências variantes presentes em uma única planta (Goszczynski \& Jooste, 2002). No presente trabalho, devido ao fato de os géis de SSCP terem sido feitos com produtos de amplificações obtidos a partir de plasmídeos recombinantes, ou seja, as seqüências variantes foram previamente individualizadas em clones, não se constataram bandas adicionais.

A ocorrência de seqüências variantes do GLRaV-1 e GLRaV-3 foi observada possivelmente devido à utilização de oligonucleotídeos degenerados para a amplificação de vírus da família Closteroviridae, utilizado para o GLRaV-3 (Tian et al., 1996), e devido à baixa temperatura de pareamento empregada. A confiabilidade da análise por SSCP depende de os oligonucleotídeos empregados na RT-PCR permitirem amplificar o maior número possível de variantes moleculares do vírus estudado. Dos sete pares de oligonucleotídeos testados, apenas dois possibilitaram amplificar os oito isolados de GVA empregados no estudo de SSCP conduzido por Goszczynski \& Jooste (2002).

As duas seqüências de nucleotídeos geradas para o GLRaV-1 apresentaram maior homologia com um isolado australiano (acesso AF195822 no GenBank), com homologias de $79,8 \%$ e $87,4 \%$. A similaridade de nucleotídeos entre as duas seqüências de GLRaV-1 foi de 79,0\% (Figura 2). Little et al. (2001) mostraram que o gene CPd2 (ORF7) do GLRaV1 é particularmente variável e que a homologia das seqüências de 28 clones de cDNA variou de $59,5 \%$ a $97 \%$ quando comparada a uma seqüencia do GLRaV-1 previamente publicada. Este resultado é similar ao obtido no presente trabalho entre as duas seqüências de nucleotídeos de parte do gene CPd2 do GLRaV-1 e a seqüência de GLRaV-1 depositada em banco de dados. A ORF 7 (CPd2) é uma das mais variáveis, sendo indicada por Little et al. (2001) para o estudo de variabilidade de isolados de GLRaV-1, o que fundamenta o estudo ora apresentado. Diversidade na seqüência de nucleotídeos também foi observada em CTV, um Closterovirus transmitido por afídeos. A comparação da seqüência de dois isolados de CTV mostrou aproximadamente $89 \%$ de homologia em 10 ORFs, mas somente $60-70 \%$ de homologia na ORF1 (Mawassi et al., 1996). Diferentemente do verificado em relação ao GLRaV-1, o baixo nível de homologia entre seqüências da ORF1 de isolados de CTV foi devido principalmente à presença de deleções.

As observações sobre a variabilidade do GLRaV-1 sugerem que este vírus pode existir na forma de uma população heterogênea, possivelmente resultante da falta de pressão seletiva ou da mistura de estirpes virais devido às práticas viticulturais de enxertia e estaquia durante longos períodos. 


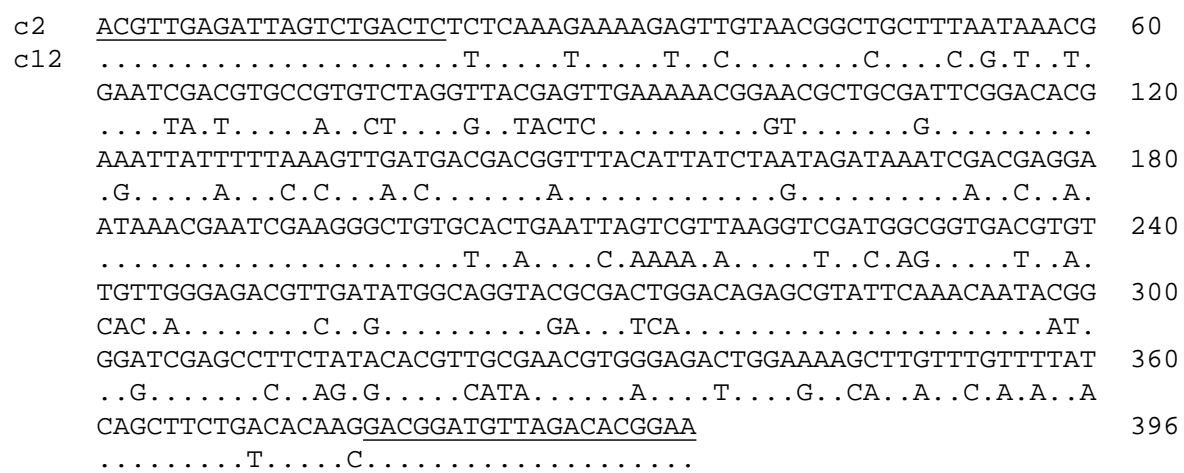

FIG. 2 - Alinhamento de nucleotídeos de duas seqüências variantes (c2 e c12) do Grapevine leafrollassociated virus 1 (GLRaV-1) no gene análogo ao da proteína capsidial (CPd2). Os pontos correspondem a nucleotídeos iguais. Bases sublinhadas referem-se aos oligonucleotídeos viral e complementar, respectivamente.

A falta de pressão seletiva em relação ao GLRaV-1 é verificada em vinhedos infetados onde não ocorrem cochonilhas vetoras deste vírus, conseqüentemente, a seleção de linhas virais puras também não ocorreria. Entre os isolados virais que se acumulam através de enxertia, ou seja, onde a transmissão por vetores não é freqüente, há, provavelmente, um aumento da heterogeneidade da população (Little et al., 2001). Para Magome et al. (1999), a presença de seqüências variantes do ASGV dentro de uma única planta pode ocorrer pela acumulação sucessiva de substituições nucleotídicas no genoma pré-existente e/ou por infecção mista de cada seqüência variante originalmente presente no porta-enxerto ou na gema usados na enxertia. Estas considerações se aplicam, mesmo que parcialmente, para explicar a presença de seqüências variantes do GLRaV-1 e 3 , pois o ASGV só é transmitido através de enxertia.

Little et al. (2001) afirmam, com base na baixa taxa de incorporação errônea de nucleotídeos, durante a amplificação do DNA pela Taq polimerase, que a variação observada nas seqüências de nucleotídeos dos diferentes clones seqüenciados é conseqüência do processo de replicação viral e da presença de variantes virais na população. Rubio et al. (1996) realizaram 30 amplificações consecutivas a partir de um único clone e observaram perfis eletroforéticos idênticos em SSCP, indicando que seria insignificante, em nível experimental, a taxa de erro atribuível à Taq polimerase.

Embora existam pressões seletivas, as alterações ocorridas nas regiões hipervariáveis, presentes nas ORFs 3 , 6 e 7 do GLRaV-1, podem permanecer na população viral se os produtos gênicos delas resultantes não apresentarem alterações que afetem a sua função na replicação viral (Little et al., 2001). As variações de seqüência, verificadas em algumas ORFs, não seriam toleradas e resultariam na extinção da variante na população viral.

As duas seqüências de nucleotídeos do GLRaV-3 exibiram maior homologia $(75,1 \%$ e $81,8 \%)$ com o isolado norte-americano NY1 (GenBank AF037268). A similaridade de nucleotídeos entre as duas seqüências de GLRaV-3 foi de 75,7\% (Figura 3). A análise da seqüência de nucleotídeos de 10 ORFs do GLRaV-1 por Little et al. (2001) revelou nível elevado e incomum de variação nas seqüências das ORFs 3, 6 e 7, que codificam uma proteína homóloga à de choque térmico 70 (HSP70) e duas cópias análogas à proteína capsidial (CPd1 e CPd2), respectivamente. Especificamente em relação ao gene HSP70 do GLRaV-1, Little et al. (2001) encontraram 109 alterações em 1629 nucleotídeos (6,7\%). Com base nos resultados obtidos no presente trabalho, a variabilidade observada por Little et al. (2001) em relação ao gene HSP70 poderia ser estendida para o GLRaV-3. Nenhuma das mudanças de nucleotídeo observadas por Little et al. (2001) resultou em mudança de fase de leitura ou na criação de um código de terminação e se notou tendência de conservação do aminoácido ou troca por aminoácido com propriedades físico-químicas similares. Não se observou criação de código de parada ou inserção/deleção de nucleotídeos em relação às seqüências variantes obtidas para os vírus GLRaV-1 e GLRaV-3 (dados não mostrados).

Magome et al. (1999) amplificaram parte da região $\mathrm{V}$ do genoma do ASGV para a análise por SSCP, devido à alta variabilidade na seqüência de nucleotídeos entre isolados nessa região, sendo, portanto, adequada para a diferenciação de seqüências variantes. Os resultados indicaram que o ASGV, dentro da planta infetada, é uma mistura de seqüências variantes. Estudo de variabilidade direcionado para regiões variáveis do genoma viral foi também conduzido, no presente trabalho, e a similaridade verificada entre as seqüências de nucleotídeos obtidas para uma mesma seqüência variante, a partir de diferentes clones, chegou perto de $100 \%$. Estas repetições consistiram em até 4 clones seqüenciados por seqüência variante.

Neste estudo foram diferenciadas seqüências variantes de GLRaV-1 e GLRaV-3 com base na similaridade de seqüências de nucleotídeos e pelos padrões gerados na análise de SSCP. Embora os fragmentos amplificados representem pequenas frações dos genomas das duas espécies virais, estes estão situados em regiões hipervariáveis do genoma (Little et al., 2001) o que tornou possível detectar variantes dos isolados do GLRaV-1 e GLRaV-3 nas amostras 
Avaliação da variabilidade do Grapevine leafroll-associated virus...

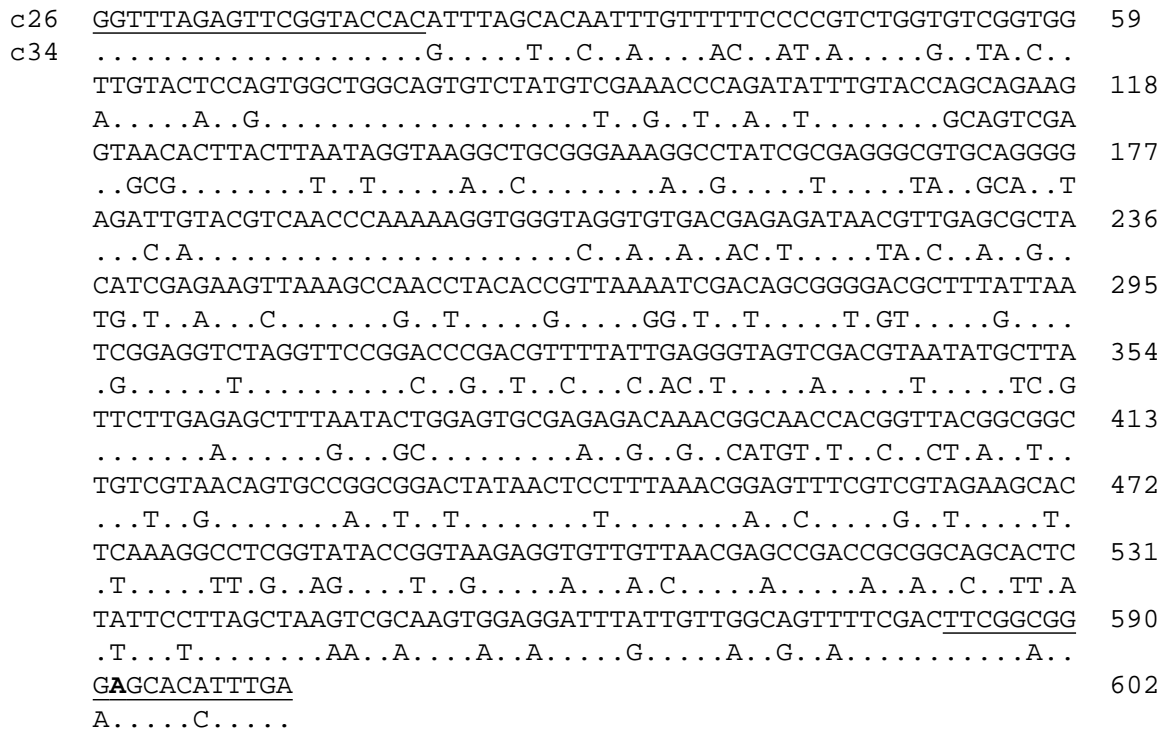

FIG. 3 - Alinhamento de nucleotídeos de duas seqüências variantes (c26 e c34) do Grapevine leafrollassociated virus 3 (GLRaV-3) no gene homólogo à proteína de choque térmico (HSP70). Os pontos correspondem a nucleotídeos iguais. Bases sublinhadas referem-se aos oligonucleotídeos viral e complementar, respectivamente, e, em negrito, a substituição de G por A no oligonucleotídeo complementar.

analisadas de videira. Também foi encontrada boa correlação entre os resultados obtidos pelos dois procedimentos adotados para o estudo de variabilidade. Desta forma, comparativamente ao seqüenciamento de nucleotídeos, a SSCP é opção útil para o estudo de variabilidade, devido à sua simplicidade, rapidez e custo relativamente baixo.

Em função da metodologia utilizada neste trabalho, ou seja, os produtos da PCR para GLRaV-1 e GLRaV-3, obtidos de diferentes plantas, após visualizados em géis de agarose, foram misturados, eluídos e clonados; não é possível afirmar que uma mesma planta possui mais de uma seqüência variante, porém foi comprovado a existência de seqüências variantes dos dois vírus.

Variações de sintomas e na severidade da doença são comuns no enrolamento das folhas da videira. Embora desconhecidas as implicações, na sintomatologia e nos aspectos epidemiológicos, da ocorrência de variantes virais detectadas em videira, o estudo de Ayllon et al. (2001) mostra que os sintomas induzidos em Citrus spp. por CTV dependem do grau de interferência entre as variantes presentes na mesma planta. Decorrência prática da presença de seqüências variantes, demonstrada no presente trabalho, é que com o bom conhecimento da variabilidade do vírus será possível selecionar os seus segmentos genômicos menos variáveis, e até invariáveis, e usá-los na detecção mais confiável mediante RT-PCR e sondas moleculares.

\section{AGRADECIMENTOS}

À Fundação de Amparo à Pesquisa do Estado do Rio Grande do Sul (FAPERGS), pela concessão da bolsa de Iniciação Científica a P.G. Schenato.

\section{REFERÊNCIAS BIBLIOGRÁFICAS}

AYLLON, M.A., LOPEZ, C., NAVAS-CASTILLO, J., GARNSEY, S.M., GUERRI, J., FLORES, R. \& MORENO, P. Polymorphism of the 5 ' terminal region of Citrus tristeza virus (CTV) RNA: Incidence of three sequence types in isolates of different origin and pathogenicity. Archives of Virology 146:27-40. 2001.

FAJARDO, T.V.M., KUHN, G.B., EIRAS, M. \& NICKEL, O. Deteç̧ão de Closterovirus em videira e caracterização parcial de um isolado do Grapevine leafroll-associated virus 3. Fitopatologia Brasileira 27:58-64. 2002.

FAJARDO, T.V.M., KUHN, G.B. \& NICKEL, O. Doenças virais. In: Fajardo, T.V.M. (Ed.). Uva para Processamento Fitossanidade. Série Frutas do Brasil, 35. Embrapa Informação Tecnológica. Brasília. 2003. pp.45-62.

FAZELI, C.F. \& REZAIAN, M.A. Nucleotide sequence and organization of ten open reading frames in the genome of Grapevine leafroll-associated virus 1 and identification of three subgenomic RNAs. Journal of General Virology 81:605-615. 2000.

GOSZCZYNSKI, D.E. \& JOOSTE, A.E.C. The application of singlestrand conformation polymorphism (SSCP) technique for the analysis of molecular heterogeneity of Grapevine virus A. Vitis 41:77-82. 2002.

GUGERLI, P. Grapevine leafroll and related viruses. Extended Abstracts, $14^{\text {th }}$ Meeting of the International Council for the Study of Virus and Virus-like Diseases of the Grapevine, Locorotondo, Italy. 2003. pp.25-31.

HABILI, N., FAZELI, C.F. \& REZAIAN, M.A. Identification of a cDNA clone specific to Grapevine leafroll-associated virus 1, and occurrence of the virus in Australia. Plant Pathology 46:516-522. 1997.

LITTLE, A., FAZELI, C.F. \& REZAIAN, M.A. Hypervariable genes in Grapevine leafroll-associated virus 1. Virus Research 80:109116. 2001. 
MAGOME, H., YOSHIKAWA, N. \& TAKAHASHI, T. Single-strand conformation polymorphism analysis of Apple stem grooving capillovirus sequence variants. Phytopathology 89:136-140. 1999.

MARTELLI, G.P. Grapevine virology highlights 2000-2003. Extended Abstracts, $14^{\text {th }}$ Meeting of the International Council for the Study of Virus and Virus-like Diseases of the Grapevine, Locorotondo, Italy. 2003. pp.3-10.

MARTELLI, G.P., AGRANOVSKY, A.A., BAR-JOSEPH, M., BOSCIA, D., CANDRESSE, T., COUTTS, R.H.A., DOLJA, V.V., FALK, B.W., GONSALVES, D., JELKMANN, W., KARASEV, A.V., MINAFRA, A., NAMBA, S., VETTEN, H.J., WISLER, G.C. \& YOSHIKAWA, N. The family Closteroviridae revised. Archives of Virology 147:2039-2044. 2002.

MAWASSI, M., MIETKIEWSKA, E., GOFMAN, R., YANG., G. \& BAR-JOSEPH, M. Unusual sequence relationships between two isolates of Citrus tristeza virus. Journal of General Virology 77:2359-
2364. 1996.

RUBIO, L., AYLLÓN, M.A., GUERRI, J., PAPPU, H., NIBLETT, C. \& MORENO, P. Differentiation of Citrus tristeza closterovirus (CTV) isolates by single-strand conformation polymorphism analysis of the coat protein gene. Annals of Applied Biology 129:479-489. 1996.

SOUZA, A.A., MÜLLER, G.W., TARGON, M.L.P.N., COLETTAFILHO, H.D. \& MACHADO, M.A. Avaliação de haplótipos do gene do capsídeo do Citrus tristeza virus em plantas pré-imunizadas de laranja Pêra. Summa Phytopathologica 28:154-159. 2002.

TIAN, T., KLAASSEN, V.A., SOONG, J., WISLER, G., DUFFUS, J.E. \& FALK, B.W. Generation of cDNAs specific to Lettuce infectious yellows closterovirus and other whitefly-transmitted viruses by RT-PCR and degenerate oligonucleotide primers corresponding to the closterovirus gene enconding the heat shock protein 70 homology. Phytopathology 86:1167-1173. 1996. 
O arquivo disponível sofreu correções conforme ERRATA publicada no Volume 30 Número 3 da revista. 